\title{
Uterine proteins and development in vitro of rabbit preimplantation embryos
}

\author{
R. R. Maurer and H. M. Beier \\ Environmental Toxicology Branch, National Institute of Environmental Health Sciences, \\ P.O. Box 12233, Research Triangle Park, North Carolina 27709, U.S.A. \\ and \\ Department of Anatomy, Medical Faculty, Rhein.-Westf. Technische Hochschule, \\ Medizin.-Theor. Institute D-5100 Aachen, West Germany
}

\begin{abstract}
Summary. The effects of isolated protein fractions from rabbit uteri (prealbumin, albumin, uteroglobin, and $\beta$-glycoprotein), unfractionated uterine proteins, progesterone, oestradiol-17 $\beta$, and prostaglandin $F-2 \alpha$ on the development of rabbit embryos in vitro were investigated. When exposed to individual protein fractions obtained from Day-6 uteri, 8-cell embryos did not develop into early blastocysts; morulae readily developed into early blastocysts, but further development was retarded. Progesterone $\left(10^{-5}-10^{-11} \mathrm{M}\right)$ and prostaglandin $\mathrm{F}-2 \alpha(0 \cdot 1-10 \mathrm{ng} / \mathrm{ml})$ added to the medium slowed development of blastocysts to advanced stages. Growth of 8- to 16-cell embryos, morulae, and Day-4 blastocysts was stimulated by unfractionated uterine proteins obtained from Day-5 uterine flushings.

Although embryos cultured in medium containing BSA had similar rates of blastocyst formation and, ultimately, similar blastocyst expansion as did the embryos cultured in medium with unfractionated proteins, the radial and immediate expansion of the early blastocysts cultured in the latter approximated that found in utero.
\end{abstract}

\section{Introduction}

The chemical composition within the rabbit uterus changes with the maternal endocrine state (Beier, Petry \& Kühnel, 1970; Beier, 1974). Before implantation, rabbit uterine fluid contains serum proteins-albumin, IgG, and $\alpha$-macroglobulin-and proteins secreted by the endometriumprealbumin, uteroglobin (=blastokinin), and $\beta$-globulins (Beier, 1967, 1968; Krishnan \& Daniel, 1967). Similar proteins are found in the fluid from Day 6 blastocysts (Beier, 1967; Kirchner, 1969; Hamana \& Hafez, 1970), although 2- to 8-cell embryos, developing to the blastocyst stage in vitro, produce albumin but not detectable amounts of proteins like those found in the uterine lumen (Beier \& Maurer, 1975).

Before implantation, embryo development and endometrial secretions must be synchronized for maximal reproductive efficiency as studies on asynchronous embryo transfer and delayed secretion have shown (Kendle \& Telford, 1970; Beier, Mootz \& Kühnel, 1972). The molecular mechanism by which the uterine secretions produce this synchrony has not been elucidated. Krishnan \& Daniel (1967) claimed that blastokinin (uteroglobin) was necessary for endogenous regulation of blastocyst development. Maurer, Onuma \& Foote (1970), however, cultured 2- and 4-cell rabbit embryos to hatching blastocysts with only bovine serum albumin (BSA) in the medium.

The present study was undertaken to determine the significance of various protein supplements obtained from the uterine flushings of 5- or 6-day pregnant rabbits for the development of preimplantation embryos in vitro. Ovarian steroids associated with the proteins were also added to the culture medium to determine their effect on embryonic development. 


\section{Materials and Methods}

\section{General procedures}

Embryos were collected from FSH-primed Dutch-Belted does at various times after the LH injection (Maurer \& Foote, 1971): e.g. 2- to 4-cell, 26-32 hr; 8- to 16-cell, 36-43 hr; morulae, 60-68 hr; and Day-4 blastocysts, $90-92 \mathrm{hr}$. The embryos were washed and pooled according to their developmental stages.

The culture medium was a glucose-salt solution supplemented with amino acids (Kane \& Foote, 1970 ) with a pH of 7.4 and a measured osmolarity of 270 mosmol (Naglee, Maurer \& Foote, 1969). To the control medium, 1 or $15 \mathrm{mg}$ BSA (Pentax, 4 times recrystallized)/ml was added. The embryos were cultured at increased atmospheric pressure $\left(16\right.$ in $\mathrm{H}_{2} \mathrm{O}$ or $\left.4052 \mathrm{~N} / \mathrm{m}^{2}\right)$ as reported by Elliott, Maurer \& Staples (1974) except that medical fluid was not used.

Every $24 \mathrm{hr}$ the embryos were classified as morulae or less, early blastocysts (beginnings of a blastocoele), blastocysts (fully developed blastocoele), expanded and/or hatching blastocysts (Elliott et al., 1974).

\section{Statistical evaluation}

The significance of among group differences was assessed by Kruskal-Wallis tests. Jonckheere's test was used to determine significant dose-related responses. If the Kruskal-Wallis or the Jonckheere test was significant, then pair comparisons between groups were made by two-sided Mann-Whitney U tests (Hollander \& Wolfe, 1973).

\section{Experiment I}

To determine the effect of uterine protein fractions on embryo growth, 8-cell and morula-stage embryos were cultured in media containing only those proteins. The uteri of 6 -day pregnant rabbits were flushed with physiological saline. The flushings were pooled, concentrated by collodium capsules (Type SM 13200 Sartorius, Goettingen), and separated into different protein fractions by slab gel electrophoresis using $7.5 \%$ polyacrylamide gel. The protein fractions were cut out, eluted from the gel using physiological saline, dialysed for $36 \mathrm{hr}$ against twice-distilled water, and freeze dried. The four protein fractions, prealbumin, albumin, uteroglobin and $\beta$-glycoprotein, at levels of 0.1 to $3.2 \mathrm{mg} / \mathrm{ml}$ were added to the medium. The control medium contained 0,1 or $15 \mathrm{mg} \mathrm{BSA} / \mathrm{ml}$. Three to 5 embryos were placed in each $\mathrm{ml}$ of medium.

Total progestin and progesterone content of each protein fraction was determined by the radioimmunoassay method described by Addison, Hammond, Tyrey \& Schomberg (1976). The radioimmunoassay for oestrogens followed the method described by Pupkin, Schomberg, Nagey \& Crenshaw (1975).

\section{Experiment II}

The effect of progesterone, oestradiol-17ß, and prostaglandin (PG) F-2 $\alpha$ on the growth of 2-, 4and 8-cell embryos in vitro was determined. Four or 5 embryos were placed in $1 \mathrm{ml}$ medium containing $15 \mathrm{mg} \mathrm{BSA} / \mathrm{ml}$. Progesterone or oestradiol-17 $\beta$ was added in $1 \mu \mathrm{l}$ of $95 \%$ ethyl alcohol to achieve $0,10^{-5}, 10^{-8}$ and $10^{-11} \mathrm{M}$ concentrations. To a third group of embryos, an aqueous prostaglandin F-2 $\alpha$ THAM salt solution was added in $1 \mu$ to achieve concentrations of $0,0 \cdot 1,1$ and $10 \mathrm{ng} / \mathrm{ml}$. The development of the 2-and 4-cell embryos was recorded every $24 \mathrm{hr}$ for $72 \mathrm{hr}$ and of the 8-cell embryos for $48 \mathrm{hr}$.

\section{Experiment III}

Unfractionated uterine proteins from Day-5 pregnant uteri were added to the medium to determine their effects on development of preimplantation embryos in vitro. Uterine secretions from pregnant 
Dutch-Belted does were collected as described in Exp. I, centrifuged at $2500 \mathrm{~g}$ for $10 \mathrm{~min}$, concentrated (Amicon Minicon B-15) for 2-4 hr at $5^{\circ} \mathrm{C}$, and analysed for protein content (Lowry, Rosebrough Farr \& Randall, 1951). Embryos at the 8- to 16-cell, morula and early blastocyst (Day 4) stage of development were collected and pooled. The Day-4 blastocysts were divided into two groups, small (av. diam. $310 \mu \mathrm{m}$ ) and large (av. diam. $838 \mu \mathrm{m}$ ). From 3 to 6 embryos of each stage were placed in $1 \mathrm{ml}$ medium supplemented with no protein, $15 \mathrm{mg} \mathrm{BSA}$, or 0.5 or $2.0 \mathrm{mg}$ unfractionated proteins. Each treatment was repeated 3 to 7 times. Morphological stages and/or blastocyst diameters were recorded every $24 \mathrm{hr}$ for $120 \mathrm{hr}$.

\section{Results}

\section{Experiment I}

Only $3 / 82,6 / 67,0 / 80$, and $2 / 698$-cell embryos developed to the early blastocyst stage when cultured in medium containing $0.2-3.2 \mathrm{mg}$ prealbumin, albumin, uteroglobin and $\beta$-glycoprotein $/ \mathrm{ml}$, respectively; none developed a full blastocoele (blastocyst). No relationship between embryo development and uterine protein quality or quantity was found. More embryos developed $(P<0.05)$ to early blastocysts in medium containing BSA at $15 \mathrm{mg} / \mathrm{ml}(30 / 32)$ than at $1 \mathrm{mg} / \mathrm{ml}(21 / 29)$, but the latter was more effective $(P<0.05)$ than any of the other protein fractions, except uterine albumin at $3.2 \mathrm{mg} / \mathrm{ml}$.

Table 1. Proportion of morula-stage rabbit embryos which developed into early blastocysts (beginning of cavity) and blastocysts (full cavity) after culture for $24 \mathrm{hr}$ in a medium containing BSA or uterine protein fractions obtained from flushing 6-day pregnant uteri (numbers for uterine protein fractions represent the sum of 1-5 replicates with

3-5 embryos/replicate; numbers for BSA represent the sum of 5-8 replicates of 2-5 embryos/replicate)

\begin{tabular}{|c|c|c|c|c|c|}
\hline \multirow{2}{*}{$\begin{array}{l}\text { Protein conc. } \\
(\mathrm{mg} / \mathrm{ml})\end{array}$} & \multirow[b]{2}{*}{ BSA } & \multicolumn{4}{|c|}{ Uterine protein fractions } \\
\hline & & Prealbumin & Albumin & Uteroglobin & $\beta$-Glycoprotein \\
\hline \multicolumn{6}{|c|}{ Morulae developing a blastocoele } \\
\hline 0.0 & $28 / 37$ & - & - & - & - \\
\hline 0.1 & & $2 / 15$ & $12 / 15$ & $13 / 15$ & $11 / 15$ \\
\hline 0.2 & & $8 / 24$ & $19 / 24$ & $19 / 26$ & $20 / 26$ \\
\hline 0.4 & & $7 / 14$ & $10 / 14$ & $12 / 16$ & $10 / 16$ \\
\hline 0.8 & & $6 / 9$ & $7 / 9$ & $10 / 16$ & $8 / 16$ \\
\hline $1 \cdot 0$ & $23 / 26$ & - & - & - & - \\
\hline 1.6 & & $3 / 9$ & $7 / 9$ & $6 / 9$ & $6 / 10$ \\
\hline $3 \cdot 2$ & & $3 / 3$ & $3 / 9$ & $4 / 8$ & $3 / 9$ \\
\hline $15 \cdot \overline{0}$ & $26 / 31$ & - & - & - & - \\
\hline Total* & $77 / 94$ & $29 / 74$ & $58 / 80$ & $64 / 90$ & $58 / 91$ \\
\hline$\%( \pm$ S.E.M. $)$ & $83 \pm 4^{a}$ & $42 \pm 9^{d}$ & $70 \pm 6^{\mathrm{ab}}$ & $73 \pm 5^{a b}$ & $62 \pm 8^{c}$ \\
\hline \multicolumn{6}{|c|}{ Morulae developing into blastocysts } \\
\hline 0.0 & $19 / 37$ & - & - & - & - \\
\hline $0 \cdot 1$ & & $0 / 15$ & $7 / 15$ & $5 / 15$ & $8 / 15$ \\
\hline $0 . \overline{2}$ & & $3 / 24$ & $10 / 24$ & $9 / 26$ & $16 / 26$ \\
\hline 0.4 & & $3 / 14$ & $8 / 14$ & $6 / 16$ & $8 / 16$ \\
\hline 0.8 & & $1 / 9$ & $5 / 9$ & $5 / 16$ & $7 / 16$ \\
\hline $1 \cdot 0$ & $23 / 26$ & - & - & - & - \\
\hline 1.6 & & $0 / 9$ & $0 / 9$ & $2 / 9$ & $1 / 10$ \\
\hline $3 \cdot 2$ & & $0 / 3$ & $0 / 9$ & $0 / 8$ & $1 / 9$ \\
\hline $15 \cdot 0$ & $25 / 31$ & - & - & - & - \\
\hline Total ${ }^{*}$ & $67 / 94$ & $7 / 74$ & $30 / 80$ & $27 / 90$ & $41 / 91$ \\
\hline$\%( \pm$ S.E.M. $)$ & $73 \pm 6^{a}$ & $9 \pm 5^{\mathrm{c}}$ & $36 \pm 10^{b}$ & $29 \pm 7^{b}$ & $43 \pm 8^{b}$ \\
\hline
\end{tabular}

Groups with the same superscript within rows do not differ statistically $(P>0 \cdot 10)$.

* Concentrations of uterine protein fractions or BSA were combined since no significant differences were found among them. 
Morulae readily developed into early blastocysts when uterine protein fractions were added to the medium (Table 1), but increased concentrations did not increase development. Medium containing uterine prealbumin significantly inhibited $(P<0.05)$ embryo growth: fewer embryos developed into early blastocysts than in medium with no protein. Significantly $(P<0.05)$ fewer embryos cultured in medium containing $\beta$-glycoprotein reached the early blastocyst stage than those cultured in BSAenriched medium. Embryo development to the blastocyst stage was significantly reduced $(P<0.05)$ when uterine protein fractions were added to the medium in place of BSA; medium with uterine prealbumin and uteroglobin permitted fewer $(P<0.05)$ embryos to develop to the blastocyst stage than medium with no protein.

The concentrations of total progestin and progesterone associated with the uterine prealbumin, albumin, uteroglobin, and B-glycoprotein fractions were 806 (not measured), 1625 (797), 453 (316), and $438(127) \mathrm{pg} / \mathrm{mg}$, respectively. The oestrogen content for each fraction was $<10 \mathrm{pg} / \mathrm{mg}$ protein. Proportionally more progesterone was associated with the uteroglobin fraction than the other fractions; BSA (15 mg) did not have detectable ( $<10 \mathrm{pg})$ progestins or oestrogens.

\section{Experiment II}

At the levels used in culture, neither oestradiol-17 $\beta$ nor progesterone produced a statistically significant effect on the percentage of early blastocysts formed from 2- to 4- or 8-cell embryos (Table 2). Since no dose-related response for advanced development of either cleavage stage was observed, the data were combined for each steroid and cleavage stage and compared to the respective control value. The mean ( \pm S.E.M.) values for 2 - to 4-cell embryos which developed into expanding and hatching blastocysts when cultured with no steroid, oestradiol-17 $\beta$ and progesterone were $26 \pm 10$, $19 \pm 6$, and $10 \pm 3 \%$, respectively; corresponding values for the 8-cell embryos were $61 \pm 3,57 \pm 8$ and $43 \pm 7 \%$. Eight-cell embryos cultured in medium containing progesterone yielded fewer $(P<$ 0.05 ) expanding and hatching blastocysts than controls.

Table 2. Development in vitro of 2- to 4-, and 8-cell rabbit embryos in a medium containing oestradiol-17及 or progesterone

\begin{tabular}{|c|c|c|c|c|c|}
\hline Hormone & $\begin{array}{l}\text { Conc. } \\
\text { (M) }\end{array}$ & $\begin{array}{l}\text { No. of } \\
\text { embryos }\end{array}$ & $\begin{array}{l}\text { No. of } \\
\text { replicates }\end{array}$ & 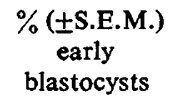 & $\begin{array}{c}\%( \pm \text { S.E.M. }) \\
\text { hatched }+ \text { expanding } \\
\text { blastocysts }\end{array}$ \\
\hline \multicolumn{6}{|c|}{ Development of 2- to 4-cell embryos after $72 \mathrm{hr}$ culture } \\
\hline $0 \cdot 1 \%$ ETOH & Control & 34 & 7 & $65 \pm 5$ & $26 \pm 10$ \\
\hline Oestradiol-17及 & $\begin{array}{l}10^{-11} \\
10^{-8} \\
10^{-5}\end{array}$ & $\begin{array}{l}39 \\
39 \\
39\end{array}$ & $\begin{array}{l}8 \\
8 \\
8\end{array}$ & $\begin{array}{l}59 \pm 11 \\
54 \pm 13 \\
54 \pm 12\end{array}$ & $\begin{array}{l}16 \pm 10 \\
34 \pm 12 \\
11 \pm 7\end{array}$ \\
\hline Progesterone & $\begin{array}{l}10^{-11} \\
10^{-8} \\
10^{-5}\end{array}$ & $\begin{array}{l}39 \\
39 \\
39\end{array}$ & $\begin{array}{l}8 \\
8 \\
8\end{array}$ & $\begin{array}{l}70 \pm 10 \\
56 \pm 6 \\
67 \pm 10\end{array}$ & $\begin{array}{r}17 \pm 8 \\
3 \pm 3 \\
11 \pm 6\end{array}$ \\
\hline \multicolumn{6}{|c|}{ Development of 8 -cell embryos after $48 \mathrm{hr}$ culture } \\
\hline $0.1 \%$ ЕTOH & Control & 23 & 5 & $86 \pm 6$ & $61 \pm 3$ \\
\hline Oestradiol-17 $\beta$ & $\begin{array}{l}10^{-11} \\
10^{-8} \\
10^{-5}\end{array}$ & $\begin{array}{l}28 \\
28 \\
28\end{array}$ & $\begin{array}{l}6 \\
6 \\
6\end{array}$ & $\begin{array}{l}85 \pm 5 \\
85 \pm 5 \\
90 \pm 7\end{array}$ & $\begin{array}{l}53 \pm 15 \\
58 \pm 17 \\
61 \pm 12\end{array}$ \\
\hline Progesterone & $\begin{array}{l}10^{-11} \\
10^{-8} \\
10^{-5}\end{array}$ & $\begin{array}{l}28 \\
28 \\
23\end{array}$ & $\begin{array}{l}6 \\
6 \\
5\end{array}$ & $\begin{array}{l}97 \pm 3 \\
76 \pm 13 \\
81 \pm 9\end{array}$ & $\begin{array}{l}43 \pm 12 \\
40 \pm 9 \\
46 \pm 16\end{array}$ \\
\hline
\end{tabular}

PGF-2 $\alpha$ at $0 \cdot 1,1$, and $10 \mathrm{ng} / \mathrm{ml}$ did not influence early blastocyst development from the 2-, 4- or 8-cell stages (Table 3), but significantly $(P<0.05)$ decreased development to advanced stages. The proportion of advanced blastocysts was $21 \pm 5$ and $45 \pm 11 \%$ of 2 - to 4-cell embryos cultured 
with and without PGF-2 $\alpha$, respectively, and $46 \pm 4 \%$ and $71 \pm 6$, for the 8-cell embryos. Although no significant dose-related response was found, concentrations of 0.1 and $1.0 \mathrm{ng} / \mathrm{ml}$ reduced $(P<0.01)$ development into expanding and hatching blastocysts. A dose of $10 \mathrm{ng}$ PGF- $2 \alpha / \mathrm{ml}$ also reduced $(P<0.05)$ development of 8 -cell embryos into advanced blastocysts.

Table 3. Development of 2- to 4-, and 8-cell rabbit embryos in a medium containing prostaglandin F-2 $\alpha$

\begin{tabular}{|c|c|c|c|c|}
\hline $\begin{array}{l}\text { PGF- } 2 \alpha \text { conc. } \\
(\mathrm{ng} / \mathrm{ml})\end{array}$ & No. of embryos & No. of replicates & $\begin{array}{c}\%( \pm \text { S.E.M. }) \\
\text { early blastocysts }\end{array}$ & $\begin{array}{c}\%( \pm \text { S.E.M. }) \\
\text { hatched + expanding } \\
\text { blastocysts }\end{array}$ \\
\hline \multicolumn{5}{|c|}{ Development of 2- to 4-cell embryos after $72 \mathrm{hr}$ culture } \\
\hline $\mathbf{0}$ & 39 & $\mathbf{8}$ & $67 \pm 7$ & $45 \pm 11$ \\
\hline $0 \cdot 1$ & 39 & 8 & $69 \pm 6$ & $16 \pm 10^{*}$ \\
\hline $1 \cdot 0$ & 38 & 8 & $71 \pm 7$ & $17 \pm 7^{* *}$ \\
\hline $10 \cdot 0$ & 34 & 7 & $69 \pm 11$ & $30 \pm 11$ \\
\hline \multicolumn{5}{|c|}{ Development of 8-cell embryos after $48 \mathrm{hr}$ culture } \\
\hline 0 & 28 & 6 & $86 \pm 7$ & $71 \pm 6$ \\
\hline $\mathbf{0} \cdot \mathbf{1}$ & 28 & 6 & $90 \pm 7$ & $47 \pm 7^{* *}$ \\
\hline $1 \cdot 0$ & 24 & 5 & $96 \pm 4$ & $43 \pm 9 * *$ \\
\hline $10 \cdot 0$ & 28 & 6 & $100 \pm 0$ & $50 \pm 4^{* *}$ \\
\hline
\end{tabular}

Significantly different from control, $* P<0.01 ; * * P<0.05$

Table 4. Development in vitro of preimplantation rabbit embryos (no. in parentheses) cultured in medium without protein, or with BSA or unfractionated uterine proteins (numbers represent mean $\% \pm$ S.E.M. of 3-4 replicates with 4-5 embryos/replicate)

\begin{tabular}{|c|c|c|c|c|}
\hline \multirow{2}{*}{$\begin{array}{c}\text { Time in culture } \\
\text { (hr) }\end{array}$} & \multirow[b]{2}{*}{ No protein } & \multirow{2}{*}{$\begin{array}{c}\text { BSA } \\
(15 \mathrm{mg} / \mathrm{ml})\end{array}$} & \multicolumn{2}{|c|}{ Unfractionated uterine proteins } \\
\hline & & & $0.5 \mathrm{mg} / \mathrm{ml}$ & $2.0 \mathrm{mg} / \mathrm{ml}$ \\
\hline \multicolumn{5}{|c|}{ 8- to 16-celled embryos developing into blastocysts } \\
\hline & (20) & (20) & (21) & (20) \\
\hline 24 & $0^{a}$ & $0^{a}$ & $0^{\mathrm{a}}$ & $0^{\mathbf{a}}$ \\
\hline 48 & $30 \pm 10^{a}$ & $65 \pm 10^{\mathrm{a}}$ & $47 \pm 11^{a}$ & $35 \pm 17^{a}$ \\
\hline 72 & $15 \pm 10^{b}$ & $95 \pm 5^{2}$ & $69 \pm 18^{a}$ & $100 \pm 0^{a}$ \\
\hline 96 & $0^{\mathrm{b}^{-}}$ & $95 \pm 5^{a}$ & $25 \pm 15^{b}$ & $95 \pm 5^{2}$ \\
\hline 120 & $0^{\epsilon}$ & $100 \pm 0^{2}$ & $20 \pm 14^{\mathrm{c}}$ & $60 \pm 8^{b}$ \\
\hline \multicolumn{5}{|c|}{ Morulae developing into blastocysts } \\
\hline & (13) & (12) & (16) & (16) \\
\hline 24 & $38 \pm 12$ & $42 \pm 8$ & $50 \pm 10$ & $56 \pm 6$ \\
\hline 48 & $44 \pm 16$ & $50 \pm 0$ & $44 \pm 12$ & $56 \pm 6$ \\
\hline 72 & $0^{a-}$ & $33 \pm 8^{b}$ & $0^{\mathbf{a}}$ & $38 \pm 12^{b}$ \\
\hline 96 & $0^{a}$ & $33 \pm 8^{b}$ & $6 \pm 6^{a b}$ & $38 \pm 12^{b}$ \\
\hline 120 & 0 & 0 & 0 & $6 \pm 6$ \\
\hline \multicolumn{5}{|c|}{ Maintenance andlor expansion of Day-4 blastocysts* } \\
\hline & (29) & (29) & (29) & (30) \\
\hline 0 & $100 \pm 0$ & $100 \pm 0$ & $100 \pm 0$ & $100 \pm 0$ \\
\hline 24 & $95 \pm 5$ & $95 \pm 5$ & $100 \pm 0$ & $100 \pm 0$ \\
\hline 48 & $100 \pm 0$ & $86 \pm 10$ & $90 \pm 6$ & $90 \pm 6$ \\
\hline 72 & $95 \pm 5$ & $81 \pm 14$ & $95 \pm 5$ & $77 \pm 12$ \\
\hline 96 & $81 \pm 14$ & $81 \pm 14$ & $86 \pm 10$ & $84 \pm 6$ \\
\hline 120 & $66 \pm 14$ & $83 \pm 14$ & $77 \pm 10$ & $80 \pm 8$ \\
\hline
\end{tabular}

Groups with the same superscript within rows do not differ statistically $(P>0 \cdot 10)$.

* No significant $(P>0 \cdot 10)$ among-group differences. 


\section{Experiment III}

The densitometric tracing of the disc gel of unfractionated uterine protein showed that the main components were albumin and uteroglobin (40-50\%). Development of blastocysts from 8- to 16-cell embryos was significantly decreased $(P<0.05)$ after $72 \mathrm{hr}$ in a medium without protein (Table 4). Blastocysts developed from 8- to 16-cell embryos maintained their viability longer in media with $2.0 \mathrm{mg}$ unfractionated protein $/ \mathrm{ml}$ and BSA than in media containing $0.5 \mathrm{mg}$ unfractionated protein/ $\mathrm{ml}$ or no protein. After $72 \mathrm{hr}$ in a medium without protein or with $0.5 \mathrm{mg}$ unfractionated protein $/ \mathrm{ml}$, more $(P<0.01)$ early blastocysts, developed from morulae, degenerated than embryos placed in medium containing BSA or $2.0 \mathrm{mg}$ unfractionated protein $/ \mathrm{ml}$.

The 8- to 16-cell embryos cultured in medium with $2.0 \mathrm{mg}$ unfractionated protein/ $\mathrm{ml}$ had larger diameters at $72 \mathrm{hr}$ than those cultured in medium with BSA; however, by 96 and $120 \mathrm{hr}$ this difference had disappeared (Table 5). Embryos cultured with unfractionated uterine protein expanded radially, whereas, most embryos cultured with BSA hatched. Diameters of hatching blastocysts were difficult to measure and are not included in Table 5. Blastocysts which expanded radially in medium containing BSA had diameters similar to those of blastocysts cultured with $2.0 \mathrm{mg}$ unfractionated protein $/ \mathrm{ml}$ at 96 and $120 \mathrm{hr}$. No early blastocysts developed from 8- to 16-cell embryos expanded when the medium was deficient in protein.

Morula-stage embryos cultured in a medium containing unfractionated uterine protein $(2.0 \mathrm{mg} / \mathrm{ml})$ produced larger $(P<0.05)$ blastocyst diameters than did embryos in media with and without BSA (Table 5).

After $48 \mathrm{hr}$, the small blastocysts cultured in medium with unfractionated protein $(2.0 \mathrm{mg} / \mathrm{ml})$ had significantly larger $(P<0.05)$ diameters than those cultured with BSA (Table 5); they remained larger until $96 \mathrm{hr}$, when those cultured with BSA were of equal size. At $120 \mathrm{hr}$ the blastocysts in both these groups were larger $(P<0.05)$ than those in the other two groups. No significant $(P>0 \cdot 10)$ differences in blastocyst diameters among treatments and culture times were found for the large ( $838 \mu \mathrm{m}$ initially) Day-4 blastocysts. Small and large blastocysts cultured for $120 \mathrm{hr}$ in medium containing BSA doubled their diameters.

\section{Discussion}

The results of this study indicate that embryonic development in vitro can be influenced by uterine proteins. Uteroglobin $(0.05$ to $1.0 \mathrm{mg} / \mathrm{ml})$ has been reported to promote blastocoele formation and blastocyst expansion in vitro of morula stage embryos (Krishnan \& Daniel, 1967); however, our results do not confirm this finding. The uteroglobin fraction from Day- 6 pregnant uteri did not support development of 8-cell embryos to the blastocyst stage in vitro and at the morula stage it retarded blastocyst formation. Morulae cultured in uterine albumin-, $\beta$-glycoprotein-, or BSA-supplemented medium produced as many or more early and late blastocysts as did uteroglobin-supplemented medium. Prealbumin retarded the development of morulae to early and late blastocysts, indicating that different uterine proteins exert different effects on embryonic development.

The association of progesterone with the uteroglobin fraction agrees with previous findings (Arthur, Cowan \& Daniel, 1972; Beato \& Baier, 1975). Although the amount of progesterone associated with the protein was small, it was surprising to find any after the purification process, since binding affinity was estimated to be $2.6 \times 10^{-6} \mathrm{M}$ in an in-vitro system (Beato \& Baier, 1975). Freeze drying and dialysis also have been reported to decrease the binding of progesterone to uteroglobin (Arthur et al., 1972). Uterine albumin had equal amounts of progesterone and other progestins and both were in larger amounts than found in uteroglobin, but $\beta$-glycoprotein had less progesterone associated with it than other progestins.

Progesterone concentrations of $3 \times 10^{-5} \mathrm{M}$ or greater inhibited cleavage of rabbit embryos in vitro (Daniel \& Levy, 1964; Daniel, 1964). However, in the present study development of embryos, especially 8-cell embryos, into hatching and expanding blastocysts was reduced by low levels of progesterone $\left(10^{-5}-10^{-11} \mathrm{M}\right)$. No dose-response relationship was found indicating some toxicity at 


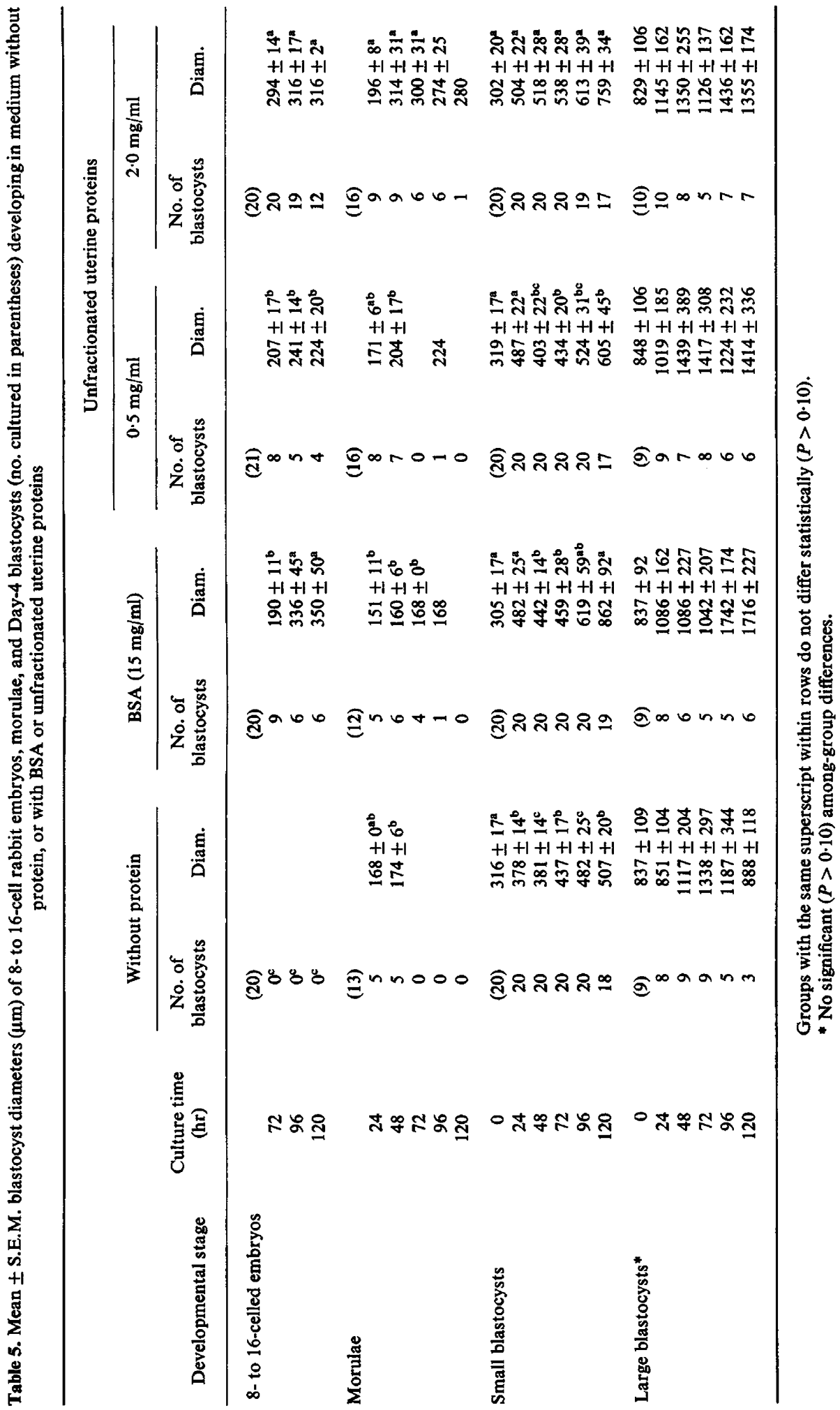


all levels used. The reduction of blastocyst development of morulae cultured in medium containing 1.6 or $3.2 \mathrm{mg}$ prealbumin, albumin, or uteroglobin may have resulted from the progesterone associated with the proteins, since $3.2 \mathrm{mg}$ uterine albumin and uteroglobin contained $8 \times 10^{-12}$ and $3.2 \times$ $10^{-12} \mathrm{M}$ progesterone, respectively. On the other hand, the oestradiol-17 $\beta$ levels $\left(10^{-5}-10^{-11} \mathrm{M}\right)$ used in this study produced no adverse effects.

Previous studies of exposure of rabbit or mouse embryos to high levels of PGF-2 $\alpha$ or PGEs reported no effect on in-vitro and subsequent in-vivo development (Chaudhuri \& Harvey, 1974; Kirkpatrick, 1974). We found that PGF-2 $\alpha$, like progesterone, had no effect on early blastocyst formation but significantly $(P<0.05)$ reduced development into expanding and hatching blastocysts.

Unfractionated uterine protein appeared to be more efficient than BSA in promoting embryonic development since $2 \mathrm{mg}$ maintained development at a rate equal to or greater than $15 \mathrm{mg} \mathrm{BSA}$, and BSA did not have the immediate stimulatory effect that the unfractionated protein $(2.0 \mathrm{mg} / \mathrm{ml})$ had. However, BSA ultimately sustained some embryo development to the expanding and hatching stage. With the addition of unfractionated protein to the medium in place of BSA, expansion of blastocysts occurred more uniformly over the whole surface, like blastocyst expansion in utero. Unfractionated and combined uterine proteins were reported to increase amino acid and uridine uptake by morulae and Day-5 blastocysts in vitro compared with that by embryos in medium without supplement (El-Banna \& Daniel, 1972a, b). However, the combined proteins did not promote more amino acid and uridine uptake than the best individual fraction. In our study, the unfractionated proteins produced embryonic growth more nearly resembling that found in utero. The uterine proteins appeared to be catabolized by the embryos or deteriorated during culture, because the percentage of embryos developing into early blastocysts increased with an increase in unfractionated protein. In vivo, the concentration of uterine proteins, especially uteroglobin, increases until Day 5 , thereby assuring the embryos an adequate supply of protein.

The molecular activity of the uterine luminal proteins has not been elucidated. Uteroglobin may protect the embryo from possible deleterious effects of free progesterone since physiological levels of progesterone $\left(10^{-11} \mathrm{M}\right)$ appear to retard embryonic development. Normal embryo growth occurs only when uterine secretions and embryonic development are in synchrony; if uterine secretions are advanced beyond the level required for the stage of embryo development, the embryo usually dies (Kendle \& Telford, 1970). If insufficient amounts of uteroglobin are present or if the secretion patterns of uterine protein are altered, the embryo usually develops a blastocoele but expansion does not occur and implantation fails (Beier, 1974).

This investigation was supported in part by a grant to H.M.B. by the Deutsche Forschungsgemeinschaft (Be 524/4) Bonn-Bad Godesberg, West Germany. We are most grateful to Dr J. K. Haseman for the statistical analyses and to Mr Franklin Schwartz and Ms Patricia Watkins for their excellent technical assistance. The progesterone and oestrogen radioimmunoassays were conducted by $\mathrm{Dr}$ D. W. Schomberg, Department of Perinatal Medicine, Duke University, Durham, N.C., on a service contract from NIEHS.

\section{References}

Addison, W.A., Hammond, C.B., Tyrey, L. \& SchomBERG, D.W. (1976) Gonadotropin release in patients with androgen-insensitivity (testicular feminization syndrome). Obstet. Gynec., N.Y. 47, 331-336.

Arthur, A.T., CowaN, B.D. \& Daniel, J.C., JR (1972) Steroid binding to blastokinin. Fert. Steril. 23, 85-92.

BEATO, M. \& BAIER, R. (1975) Binding of progesterone to the proteins of the uterine luminal fluid. Identification of uteroglobin as the binding protein. Biochim. biophys. Acta 392, 346-356.

BeIER, H.M. (1967) Veränderungen am Proteinmuster des Uterus bei dessen Ernährungsfunktion für die
Blastocyste des Kaninchens. Verh. dr. Zool. Ges. 31, 139-148.

BEiER, H.M. (1968) Uteroglobin: a hormone-sensitive endometrial protein involved in blastocyst development. Biochim. biophys. Acta 160, 289-291.

Beier, H.M. (1974) Oviducal and uterine fluids. $J$. Reprod. Fert. 37, 221-237.

BEIER, H.M. \& MAURER, R.R. (1975) Uteroglobin and other proteins in rabbit blastocyst fluid after development in vivo and in vitro. Cell Tiss. Res. 159, 1-10.

Beier, H.M., Petry, G. \& Kühnel, W. (1970) Endometrial secretion and early mammalian development. 
In Mammalian Reproduction. pp. 264-285. Eds H. Gibian \& E. J. Plotz. Springer, Berlin.

Beier, H. M., Mootz, U. \& KühNel, W. (1972) Asynchrone Eitransplantationen während der verzögerten Uterussekretion beim kaninchen. Proc. 7th Int. Congr. Anim. Reprod \& A.I., Munich 3, 1891-1896.

Chaudhuri, G. \& Harvey, J. (1974) Absence of direct effects of prostaglandins on rabbit blastocysts in vitro. Prostaglandins 8, 253-258.

DANIEL, J.C., JR (1964) Some effects of steroids on cleavage of rabbit eggs in vitro. Endocrinology 75, 706-710.

DANIEL, J.C., JR \& LEVY, J.D. (1964) Action of progesterone as a cleavage inhibitor of rabbit ova in vitro. J. Reprod. Fert. 7, 323-329.

EL-BanNA, A.A. \& Daniel, J.C., JR (1972a) Stimulation of rabbit blastocysts in vitro by progesterone and uterine proteins in combination. Fert. Steril. 23, 101-104.

El-Banna, A.A. \& Daniel, J.C., JR (1972b) The effect of protein fractions from rabbit uterine fluids on embryo growth and uptake of nucleic acid and protein precursors. Fert. Steril. 23, 105-114.

Elijotr, D.S., MaURer, R.R. \& Staples, R.E. (1974) Development of mammalian embryos in vitro with increased atmospheric pressure. Biol. Reprod. 11, 162-167.

Hamana, K. \& HAfez, E.S.E. (1970) Disc electrophoretic patterns of uteroglobin and serum proteins in rabbit blastocoelic fluid. J. Reprod. Fert. 21, 555-558.

HollaNDER, M. \& Wolfe, D.W. (1973) Nonparametric Statistical Methods. Wiley \& Sons, New York.

KANE, M.T. \& FooTe, R. H. (1970) Culture of two- and four-cell rabbit embryos to the expanding blastocyst stage in synthetic media. Proc. Soc. exp. Biol. Med. 133, 921-925.
KENDLE, K.E. \& TELFORD, J.M. (1970) Investigations into the mechanism of the antifertility action of minimal doses of megestrol acetate in the rabbit. Br. $J$. Pharmac. 40, 759-774.

KIRCHNER, C. (1969) Untersuchungen an uterusspezifischen Glycoproteinen während der frühen Gravidität des Kaninchens, Oryctolagus cuniculus. Wilhelm Roux Arch. EntwMech. Org. 164, 97-133.

KIRKPATRICK, J.K. (1974) The absence of direct effects of prostaglandin $F_{2 \alpha}$ on preimplantation mouse embryos in vitro. Prostaglandins 5, 107-113.

KRISHNAN, R. \& DANIEL, J.C., JR (1967) "Blastokinin": inducer and regulator of blastocyst development in the rabbit uterus. Science, $N . Y .158,490-492$.

Lowry, O.H., Rosebrough, N.J., FARR, A.L. \& RANDALL, R.J. (1951) Protein measurement with the folin phenol reagent. J. biol. Chem. 193, 265275.

MAURER, R.R. \& Foote, R.H. (1971) Maternal ageing and embryonic mortality in the rabbit. I. Repeated superovulation, embryo culture and transfer. $J$. Reprod. Fert. 25, 329-341.

MAURER, R.R., ONUMA, H. \& FoOTE, R.H. (1970) Viability of cultured and transferred rabbit embryos. J. Reprod. Fert. 21, 417-422.

Naglee, D.L., MaUrer, R.R. \& Foote, R.H. (1969) Effect of osmolarity on in vitro development of rabbit embryos in a chemically defined medium. Expl Cell Res. 58, 331-333.

Pupkin, M.J., Schomberg, D.W., NaGeY, D.A. \& Crenshaw, C. (1975) Effect of exogenous dehydroepiandrosterone upon the fetoplacental biosynthesis of estrogens and its effect upon uterine blood flow in the term pregnant ewe. Am. J. Obstet. Gynec. 121, 227-232. 